\section{A. Hems}

To BE a successful scientist requires three attributes: intelligence, hardwork and perspicacity. Intelligence and hard work are not enough; perspicacity, insight, flair-call it what you willmake up a somewhat undefinable third requisite. Dr D. A. Hems, Reader in Biochemistry at St George's Hospital Medical School, London, who died tragically on 2 February 1979, possessed all three qualities. He was just 40 , at the peak of his scientific career.

Hems recejved his schooling at the John Lyon school in Harrow, and entered University College, London as Bucknill Open Scholar in Medicine. At the end of his pre-clinical years, he took an intercalated Hons BSc in Physiology; during his clinical training at $\mathrm{UCH}$ he received prizes in neurology, and in obstetrics and gynaecology. On qualifying, he decided to pursue a scientific career, and moved to the Institute of Psychiatry to work on biochemical aspects of brain metabolism under Dr (now Prof.) R. Rodnight; three years later he received his PhD. Intelligence and hard work were clearly two of Hem's attributes.

Hems' interest now lay firmly in metabolism. But not in the elucidation of intermediates or in the properties of isolated enzymes. He realised that this aspect of biochemistry was, by 1966 , proceeding on fairly predictable lines. What was lacking, was a proper correlation between the physiological behaviour of an organ and the biochemical activity of its cells. In Oxford, Sir Hans Krebs was developing the technique of whole organ perfusion. So it was to Oxford, on an MRC Research Fellowship, that Hems went in 1966: the first sign of that third attribute.

In 1969 Hems was appointed Lecturer in Biochemistry at Imperial College, under Professor Sir Ernst Chain. He now began to develop what proved to be his major scientific interest: the hormonal control of metabolism, using intact organs and cells. It was clear to him, as to others at this time, that the concept of a specific target organ for a specific hormone was too restrictive. $\mathrm{He}$ showed, for example, that the antidiuretic hormone vasopressin also has a direct action on the liver; that action is to stimulate glycogen phosphorylase, but not, as Hems discovered, by way of cyclic AMP. Another of Hems' interests lay in obesity. With characteristic insight he chose to investigate fat synthesis in liver, rather than in adipose tissue: a choice that is beginning to appear well-founded. More signs of that essential third quality; sadly, fulfillment of Hems' potential was not to be realised.

During his time at Imperial College, Hems established close links with the research being carried out by $\mathrm{Dr}$ Anne Beloff-Chain (Lady Chain). He also built up an active group of his own; when in 1976 he was offered a Senior Lectureship in the new Biochemistry Department at St George's, the entire group chose to move with him to Tooting. Hems-Doug to all who were close to him-was at once immensely kind and considerate, helpful and inspiring. and it is easy to see why he was able to attract bright and energetic students, as well as more senior research workers. As a teacher, also, Hems was dedicated to his students.

His scientific achievements led to his appointment as an editor, first for Clinical Science and Molecular Medicine, and next of the Biochemical Journal. He also played an active part in the Regulation in Metabolism Group of the Biochemical Society.

Hems loved music and poetry; he particularly enjoyed witty and pithy comments on life, and was himself gifted with a dry sense of humour. The latter contributed to his demand as a guest speaker: at the time of his death, he had invitations to lecture at Guildford, London, Cairo, Cambridge and Copenhagen. But however much his scientific colleagues will miss him, it is his widow, Phyl Hems, and his two children Jacky and Clare, who face a sad and lonely future without Doug. It is to them that our sympathy is extended.

C. A. Pasternak

\section{Ralph Emerson}

WITH the death on 12 March 1979 of Professor Ralph Emerson, mycology has lost one of its brightest stars. $\mathrm{He}$ was born in New York City in 1912. He studied biology at Harvard obtaining his BS in 1933 and his PhD in 1937. He then came to England with a National Research Council fellowship and worked in the botany school at Cambridge for the next two years. In 1940 he joined the faculty of the University of Cali- fornia at Berkeley becoming a full professor in 1953 and being chairman of the botany department from 1967 to 1971.

He was elected to the National Academy of Sciences in 1970. He served as president of the Botanical Society of America (1967), as president of the Mycological Society of America (1953) and as vice-president of the British Mycological Society (1971). In 1964 he received the Merit Award of the Botanical Society of America. To the First International Mycological Congress at Exeter in 1971 he contributed a brilliant general lecture which ended in a standing ovation.

His greatest scientific contributions were to the biology of water-moulds especially those belonging to the Blastocladiales, Hans Kniep (18811930), that great student of sexuality in fungi, discovered in the last years of his life a unique sexual cycle in the water-mould Allomyces. Ralph Emerson developed the study of sex in species of that genus in beautiful detail. His "An experimental study of the life-cycles and taxonomy of Allomyces' (Lloydia 4, 77-144; 1941) has become one of the classic papers of mycology. He was also responsible for a film 'Syngamy and alteration of generations in Allomyces', one of the finest mycological films ever produced. Further, Ralph Emerson made important contributions to the physiology of water-moulds. He found that certain species require an environment with a high concentration of carbon dioxide if resting spores are to be formed. whilst in one specics oxygen must be absent if any growth is to occur, a most unusual situation in fungi.

He maintained that, although Blastocladiales were clearly not organisms of economic importance, their study could make valuable contributions to fundamental problems. $\mathrm{He}$ inspired students and colleagues to undertake work that has fully vindicated this view. He launched $\mathrm{Dr}$ Cantino on his productive study of Blastocladiella which has done so much to illuminate the relationship between biochemistry and morphology. $\mathrm{He}$ inspired the late $\mathrm{Dr}$ Machlis and his colleagues to investigate the hormone concerned with the attraction of male to female gametes in Allomyces. This led in 1968 to the 